\title{
KEPUASAN PASIEN TERHADAP PELAYANAN KESEHATAN DI KLINIK PRATAMA
}

\author{
Tonasih, Ucha Indra Gunawan \\ STIKes Muhammadiyah Cirebon, Jl. Kalitanjung Timur No.14/18 A \\ Kel./Kec. Harjamukti Kota Cirebon, 081219085783 \\ asih islamiyah@yahoo.co.id
}

\begin{abstract}
ABSTRAK
Pelayanan kesehatan merupakan salah satu faktor yang memengaruhi derajat kesehatan masyarakat. Berdasarkan data terjadi penurunan pasien sejak bulan Januari - Juni 2020. Studi pendahuluan tentang kepuasan pasien terhadap pelayanan kesehatan di Klinik Pratama Akbid Muhammadiyah Cirebon didapatkan bahwa dari 10 orang masih ada 2 orang (20\%) yang belum merasa puas terhadap pelayanan kesehatan yang meliputi kepuasan terhadap pelayanan loket pendaftaran, pelayanan dokter umum, pelayanan perawat, pelayanan dokter gigi, pelayanan bidan, pelayanan fasilitas medis dan non medis, dan keadaan lingkungan fisik. Tujuan penelitian untuk mengetahui kepuasan pasien terhadap pelayanan kesehatan di Klinik Pratama Akbid Muhammadiyah Cirebon. Jenis penelitian ini adalah deskriptif tentang kepuasan pasien terhadap pelayanan meliputi loket pendaftaran, pelayanan dokter, dan pelayanan perawat dengan subvariabel berwujud, keandalan, empati, ketanggapan, dan jaminan. Populasi adalah pasien yang datang ke Klinik pada tanggal 30 November s.d 12 Desember 2020 dengan accidental sampling sebanyak 39 orang. Instrumen menggunakan kuesioner yang berisi 15 item. Hasil penelitian didapatkan tingkat kepuasan pasien terhadap pelayanan kesehatan dalam aspek berwujud $92,09 \%$, keandalan 89,74\%, empati $94.15 \%$, ketanggapan $93.15 \%$, dan jaminan $91.32 \%$. Tingkat kepuasan secara keseluruhan $92.09 \%$ dikategorikan puas. Tidak ada hubungan antara jenis kelamin, umur, pendidikan, pekerjaan, kepesertaan BPJS.
\end{abstract}

Kata kunci: pelayanan kesehatan; tingkat kepuasan; klinik pratama

\section{PATIENT'S SATISFACTION TOWARDS HEALTH SERVICES IN THE PRATAMA CLINIC}

\begin{abstract}
Health services are one of the factors that affect the health status of the community. Based on the data, there was a decrease in patients from January to June 2020. A preliminary study on patient satisfaction with health services at the Pratama Akbid Muhammadiyah Clinic of Cirebon found that out of 10 people there were still 2 people (20\%) who were not satisfied with the health services at the Akbid Muhammadiyah Pratama Clinic of Cirebon which includes satisfaction with registration counter services, general practitioner services, nurse services, dentist services, midwife services, medical and non-medical facilities services, and the state of the physical environment. The purpose of this study was to determine the description of patient satisfaction with health services at the Akbid Muhammadiyah Pratama Clinic of Cirebon. This type of research was descriptive research. The research variable was patient satisfaction with services at the Primary Clinic Akbid Muhammadiyah of Cirebon which includes registration counters, doctor services, and nurse services with tangible subvariables, reliability, empathy, responsiveness, and assurance. The study population was patients who came to the clinic on 30 November to 12 December 2020. The sampling method was accidental sampling. The samples obtained were 39 people. Data collection started from the opening hours of registration until it was completed. The research instrument used a questionnaire containing 15 items. The results of the study were analyzed by comparing expectations and experiences that describe the level of patient satisfaction with health services in tangible aspects $92.09 \%$, reliability $89.74 \%$, empathy $94.15 \%$, responsiveness $93.15 \%$, and assurance $91.32 \%$. The overall satisfaction level of $92.09 \%$ is categorized as satisfied. Bivariate analysis results: there is no relationship between gender, age, education, occupation, Health Social Security Agency membership.
\end{abstract}

Keywords: health services; primary clinic; satisfaction level 


\section{LATAR BELAKANG}

Pelayanan Kesehatan merupakan salah satu faktor yang memengaruhi derajat kesehatan masyarakat, di mana keberadaan fasilitas kesehatan sangat menentukan dalam pelayanan pemulihan kesehatan, pencegahan terhadap penyakit, pengobatan dan keperawatan serta kelompok dan masyarakat yang memerlukan pelayanan kesehatan. (Adliyani, 2015)

Ketersediaan fasilitas kesehatan sangat dipengaruhi oleh lokasi, apakah dapat dijangkau oleh masyarakat atau tidak, tenaga kesehatan yang memberikan pelayanan, informasi dan motivasi masyarakat untuk mendatangi fasilitas dalam memperoleh pelayanan, serta program pelayanan kesehatan apakah sesuai dengan kebutuhan masyarakat. Semakin mudah akses individu atau masyarakat terhadap pelayanan kesehatan maka derajat kesehatan masyarakat semakin baik. (Eliana \& Sumiati, 2016)

Kualitas adalah sebuah kata yang bagi penyedia jasa merupakan sesuatu yang harus dikerjakan dengan baik. Keunggulan suatu produk jasa adalah tergantung dari keunikan serta kualitas yang diperlihatkan oleh jasa tersebut, apakah sudah sesuai dengan harapan dan keinginan pelanggan/penumpang. Kepuasan pasien adalah suatu tingkat perasaan pasien yang timbul sebagai akibat dari kinerja layanan kesehatan yang diperoleh setelah pasien membandingkan dengan apa yang dirasakan. Pasien akan merasa puas apabila kinerja layanan kesehatan yang diperoleh sama atau melebihi harapan. Terdapat 5 (lima) dimensi yang mewakili persepsi konsumen terhadap suatu kualitas pelayanan jasa, yaitu: keandalan, ketanggapan, jaminan, empati dan berwujud. (Sri Handayani, 2016).

Keandalan (Relaibility) adalah kemampuan untuk melaksanakan jasa yang dijanjikan dengan tepat dan terpercaya. Ketanggapan (Responsiveness) adalah kemauan untuk membantu pelanggan dan memberikan jasa dengan cepat atau ketanggapan. Jaminan (assurance) adalah dimensi kualitas pelayanan yang berhubungan dengan kemam-puan dalam menanamkan kepercayaan dan keyakinan kepada konsumen. Empati (emphaty) adalah syarat untuk peduli, memberi perhatian pribadi bagi pelanggan. Berwujud (tangible) didefinisikan sebagai penampilan fasilitas peralatan dan petugas yang memberikan pelayanan jasa karena suatu service jasa tidak dapat dilihat, dicium, diraba atau didengar maka aspek berwujud menjadi sangat penting sebagai ukuran terhadap pelayanan jasa. (Supranto, 2011).

Klinik Pratama Akbid Muhammadiyah Cirebon merupakan salah satu Amal Usaha Muhammadiyah (AUM) pertama dan satusatunya klinik yang dimiliki oleh Institusi pendidikan di Kota Cirebon yang berlokasi di kompleks STIKes Muhammadiyah Cirebon jalan Kalitanjung Timur No. 14/18 A Kel./Kec. Harjamukti Kota Cirebon. Pelayanan yang diberikan di Klinik Pratama Akbid antara lain pemeriksaan umum dan gawat darurat oleh dokter umum, kesehatan gigi dan mulut oleh dokter gigi, pelayanan KIA dan KB oleh bidan, farmasi oleh apoteker, laboratorium, oleh laboran, psikolog oleh ahli psikolog, dan rekam medik. Selain pelayanan yang diberikan Klinik Pratama Akbid juga mempunyai beberapa sarana yaitu ruang pendaftaran, ruang tunggu, ruang pemeriksaan umum, ruang pemeriksaan gigi, ruang tindakan, ruang kebidanan, ruang laboratorium, ruang Pojok ASI, ruang arena bermain anak, ruang administrasi, ruang rekam medik, ruang pencegahan infeksi, pantry, ruang rapat, dan lain-lain.

Berdasarkan pengamatan dan data yang diperoleh dari laporan Klinik Pratama Akbid Muhammadiyah Cirebon terjadi penurunan pasien sejak bulan Januari - Juni 2020 yaitu Pasien Umum bulan Januari sebanyak 190 kasus, Februari sebanyak 173 kasus, Maret sebanyak 186 kasus, April sebanyak 82 kasus, Mei sebanyak 75 kasus, Juni sebanyak 149 kasus, dan Juli sebanyak 127 kasus sedangkan pasien BPJS yaitu bulan Januari sebanyak 690 kasus, Februari sebanyak 789 kasus, Maret sebanyak 712, April sebanyak 245 kasus, Mei sebanyak 208 kasus, Juni sebanyak 407 kasus, dan bulan Juli sebanyak 308 kasus. 
Studi pendahuluan tentang kepuasan pasien terhadap pelayanan kesehatan di Klinik Pratama Akbid Muhammadiyah Cirebon didapatkan bahwa dari 10 orang masih ada 2 orang (20\%) yang belum merasa puas terhadap pelayanan kesehatan di Klinik Pratama Akbid Muhammadiyah Cirebon yang meliputi kepuasan terhadap pelayanan loket pendaftaran, pelayanan dokter umum, pelayanan perawat, pelayanan dokter gigi, pelayanan bidan, pelayanan fasilitas medis dan non medis, dan keadaan lingkungan fisik.

Berdasarkan uraian latar belakang di atas maka peneliti merasa perlu melakukan penelitian tentang Kepuasan Pasien terhadap Pelayanan Kesehatan di Klinik Pratama Akbid Muhammadiyah Cirebon.

\section{METODE}

Rancangan penelitian menggunakan deskriptif kuantitatif dengan menggunakan variabel kepuasan dan subvariabel berwujud, keandalan, ketanggapan, empati dan jaminan. Populasi penelitian adalah pasien yang datang di Klinik Pratama Akbid Muhammadiyah Cirebon pada tanggal 30 November s.d 12 Desember 2020. Teknik pengambilan sampel dengan accidental sampling. Sampel yang didapatkan sebanyak 39 responden.

Pengumpulan data dimulai dari buka pendaftaran sampai selesai dilaksanakan. Instrumen penelitian menggunakan kuesioner yang berisi 15 item pernyataan tentang kenyataan yang diterima dan harapan terhadap pelayanan kesehatan di klinik meliputi: pelayanan loket pendaftaran, pelayanan dokter umum, pelayanan perawat yang terdiri dari subvariabel berwujud sebanyak 3 pernyataan, subvariabel empati sebanyak 3 pernyataan, subvariabel ketanggapan sebanyak 3 pernyataan, subvariabel jaminan sebanyak 3 item pernyataan dan subvariabel keandalan sebanyak 3 pernyataan.

Responden diminta untuk memberikan tanda $(\mathrm{x})$ pada pernyataan yang sesuai dengan kenyataan dan harapan. Untuk pernyataan yang sesuai dengan kenyataan yang diterima, skor 1 apabila pasien sangat tidak puas, skor 2 apabila pasien tidak puas, skor 3 apabila pasien cukup puas, skor 4 apabila pasien puas dan skor 5 apabila pasien sangat puas. Untuk harapan pasien terhadap pelayanan kesehatan klinik, skor 1 apabila pernyataan sangat tidak penting, skor 2 apabila pernyataan tidak penting, skor 3 apabila pernyataan cukup penting, skor 4 apabila pernyataan penting dan skor 5 apabila pernyataan sangat penting. Teknik analisa data secara univariat dan bivariat menggunakan uji chi-square.

\section{HASIL}

Karakteristik responden penelitian meliputi; jenis kelamin, umur, pendidikan, pekerjaan, status kepesertaan, digambarkan dalam tabel berikut ini

Tabel 1 Distribusi Frekuensi Responden Berdasarkan Jenis Kelamin

\begin{tabular}{ccc}
\hline Jenis Kelamin & Frekuensi & Persentase (\%) \\
\hline Laki-laki & 18 & 46,2 \\
Perempuan & 21 & 53,8 \\
\hline Jumlah & 39 & 100 \\
\hline
\end{tabular}

Tabel 1 menunjukkan bahwa distribusi responden berdasarkan jenis kelamin sebagian besar responden berjenis kelamin perempuan yaitu sebanyak 21 orang $(53,8 \%)$.

Tabel 2 Distribusi Frekuensi Responden Berdasarkan Umur

\begin{tabular}{ccc}
\hline Umur (tahun) & Frekuensi & Persentase (\%) \\
\hline $16-24$ & 7 & 17.9 \\
$25-34$ & 14 & 35.9 \\
$35-49$ & 13 & 33.3 \\
$50-64$ & 4 & 10.3 \\
$>65$ & 1 & 2.6 \\
\hline Jumlah & 39 & 100 \\
\hline
\end{tabular}

Tabel 2 menunjukkan bahwa distribusi responden berdasarkan umur sebagian besar responden berumur 25 - 34 tahun yaitu sebanyak 14 orang $(35,9 \%)$.

Tabel 3 Distribusi Frekuensi Responden Berdasarkan Pendidikan

\begin{tabular}{ccc}
\hline Pendidikan & Frekuensi & Persentase (\%) \\
\hline SD & 2 & 5.1 \\
SMP & 7 & 17.9 \\
SMA & 19 & 48.7 \\
Diploma & 5 & 12.8 \\
Sarjana/Magister & 6 & 15.4 \\
\hline Jumlah & 39 & 100 \\
\hline
\end{tabular}


Tabel 3 menunjukkan bahwa distribusi responden berdasarkan pendidikan sebagian besar pendidikan responden yaitu SMA sebanyak 19 orang $(48,7 \%)$.

Tabel 4 Distribusi Responden Berdasarkan Pekerjaan

\begin{tabular}{ccc}
\hline Pekerjaan & Frekuensi & $\begin{array}{c}\text { Persentase } \\
(\%)\end{array}$ \\
\hline Pegawai Negeri Sipil & 1 & 2.6 \\
(PNS) & & \\
Pegawai Swasta & 14 & 35.9 \\
Pedagang & 3 & 7.7 \\
Tidak Bekerja & 21 & 53.8 \\
\hline Jumlah & 39 & 100 \\
\hline
\end{tabular}

Tabel 4 menunjukkan bahwa distribusi responden berdasarkan pekerjaan sebagian besar responden tidak bekerja yaitu sebanyak 21 orang $(53,8 \%)$.

Tabel 5 Distribusi Frekuensi Responden Berdasarkan Status Kepesertaan

\begin{tabular}{ccc}
\hline Status Kepesertaan & Frekuensi & Persentase (\%) \\
\hline Umum & 14 & 35.9 \\
BPJS & 25 & 64.1 \\
\hline Jumlah & 39 & 100 \\
\hline
\end{tabular}

Tabel 5 menunjukkan bahwa distribusi responden berdasarkan status kepesertaan sebagian besar responden menggunakan BPJS yaitu sebanyak 25 orang $(64,1 \%)$.

Pernyataan tentang kepuasan pasien terhadap pelayanan kesehatan di Klinik Pratama yang meliputi pelayanan loket pendaftaran, pelayanan dokter umum dan pelayanan perawat digambarkan berkut ini;

\section{Pelayanan loket pendaftaran}

P.1: Jam buka pendaftaran sesuai jadwal

P.2: Pendaftaran pasien berurutan dari yang datang lebih awal

P.3: Prosedur pendaftaran mudah dan tidak berbelit - belit

P.4: Petugas memberikan pelayanan dengan sopan

P.5: Waktu tunggu sebelum periksa tidak terlalu lama

\section{Pelayanan Dokter Umum}

P.6: Dokter jaga selalu ada di Klinik

P.7: Dokter memberikan informasi yang jelas dan mudah dimengerti tentang penyakit yang diderita

P.8: Dokter memeriksa dengan ramah dan sopan

P.9: Dokter memberikan tindakan yang cepat pada saat dibutuhkan

P.10: Dokter memeriksa pasien tanpa memandang status pasien

\section{Pelayanan Perawat}

P.11: Perawat memberikan pelayanan dengan ramah dan sopan

P.12: Perawat memberikan perhatian terhadap keluhan penyakit yang diderita

P.13: Perawat melayani saya dengan tulus dan penuh kasih sayang

P.14: Perawat berkomunikasi dengan santai dan Terbuka

P. 15: Perawat memberikan penjelasan yang mudah dimengerti tentang keperawatan yang diderita

Tabel 6. Distribusi Harapan dan Pelaksanaan terhadap Pelayanan Kesehatan di Klinik Pratama

\begin{tabular}{|c|c|c|c|c|c|c|c|}
\hline \multirow{2}{*}{ Pernyataan } & \multicolumn{5}{|c|}{ Pelaksanaan } & \multirow{2}{*}{ Bobot } & \multirow{2}{*}{$\begin{array}{c}\text { Nilai Indek } \\
\text { Kinerja }\end{array}$} \\
\hline & STPS & TPS & CPS & Ps & SPS & & \\
\hline P.1 & & & 8 & 21 & 10 & 158 & 91.86 \\
\hline P.2 & & & 8 & 22 & 9 & 157 & 91.81 \\
\hline P.3 & & 1 & 7 & 22 & 9 & 156 & 91.76 \\
\hline P.4 & & & 7 & 19 & 13 & 162 & 93.10 \\
\hline P.5 & & & 14 & 16 & 9 & 151 & 88.30 \\
\hline P. 6 & & 3 & 8 & 14 & 14 & 156 & 89.66 \\
\hline P.7 & & & 10 & 15 & 12 & 150 & 85.23 \\
\hline P.8 & & & 6 & 17 & 16 & 166 & 93.79 \\
\hline P.9 & & & 7 & 16 & 16 & 165 & 91.67 \\
\hline P.10 & & & 7 & 14 & 18 & 167 & 93.30 \\
\hline P.11 & & & 7 & 19 & 13 & 162 & 94.74 \\
\hline P.12 & & 1 & 11 & 17 & 10 & 153 & 92.17 \\
\hline P.13 & & 1 & 6 & 21 & 11 & 159 & 96.95 \\
\hline P.14 & & 1 & 6 & 20 & 12 & 160 & 94.67 \\
\hline P.15 & & 1 & 9 & 17 & 12 & 157 & 92.35 \\
\hline
\end{tabular}


Berdasarkan tabel 6 di atas, pada kinerja terhadap variabel pelayanan loket pendaftaran, pada kinerja terlihat sebagian besar responden menyatakan puas terutama pada pernyataan ke lima terkait waktu tunggu sebelum periksa tidak terlalu lama sebanyak 16 responden dengan bobot 151. Pelayanan dokter umum, pada kinerja terlihat sebagian besar responden menyatakan puas terutama pada pernyataan ke sembilan yaitu dokter memberikan tindakan yang cepat pada saat dibutuhkan sebanyak 16 responden dengan bobot 165 dan pernyataan ke sepuluh yaitu dokter memeriksa pasien tanpa memandang status pasien sebanyak 18 responden dengan bobot 167. Pelayanan perawat, pada kinerja terlihat sebagian besar responden menyatakan puas terutama pada pernyataan ke tiga belas yaitu Perawat melayani saya dengan tulus dan penuh kasih sayang sebanyak 21 responden dengan bobot 159.

Tabel 7. Penghitungan Tingkat Kepuasan dari Aspek Berwujud, Keandalan, Empati, Ketanggapan, dan Jaminan pada Pelayanan Kesehatan di Klinik Pratama Akbid Muhammadiyah Cirebon

\begin{tabular}{ccccc}
\hline Aspek & $\begin{array}{c}\text { Nomor } \\
\text { Pernyataan }\end{array}$ & Nilai & Prosentase & Ket \\
\hline Berwujud & P.1, P.6, & 159 & 92,09 & Puas \\
& P.11 & & & \\
Keandalan & P.2, P.7, & 153 & 89,74 & Puas \\
& P12 & & & \\
Empati & P.3, P.8, & 160 & 94,15 & Puas \\
& P.13 & & & \\
Ketanggapan & P.4, P.9, & 162 & 93,15 & Puas \\
Jaminan & P.14 & & & \\
& P.5, P.10, & 158 & 91,32 & Puas \\
& P.15 & & & \\
\hline
\end{tabular}

Berdasarkan tabel 7 di atas menunjukkan bahwa: Berdasarkan aspek Berwujud pada nomor pernyataan 1, 6, dan 11 memperoleh nilai sebesar 159 dengan prosentase 92,09 yang berarti bahwa pasien merasa puas. Berdasarkan aspek Keandalan pada nomor pernyataan 2, 7, dan 12 memperoleh nilai sebesar 153 dengan prosentase 89,74 yang berarti bahwa pasien merasa puas. Berdasarkan aspek Empati pada nomor pernyataan 3, 8, dan 13 memperoleh nilai

\section{Analisis Bivariat}

Tabel 8. Hubungan antara Jenis Kelamin dengan Kepuasan Pasien

\begin{tabular}{lllll}
\hline \multirow{2}{*}{$\begin{array}{c}\text { Jenis } \\
\text { Kelamin }\end{array}$} & \multicolumn{4}{c}{ Kepuasan } \\
\cline { 2 - 4 } & $\begin{array}{c}\text { Tidak } \\
\text { Puas }\end{array}$ & Puas & Total & $\begin{array}{c}P \\
\text { value }\end{array}$ \\
\hline Laki-laki & 2 & 16 & 18 & \\
Perempuan & 2 & 19 & 21 & 0.424 \\
\hline Total & $\mathbf{4}$ & $\mathbf{3 5}$ & $\mathbf{3 9}$ & \\
\hline
\end{tabular}

Berdasarkan tabel 8 di atas dapat diketahui sebesar 160 dengan prosentase 94,15 yang berarti bahwa pasien merasa puas. Berdasarkan aspek Ketanggapan pada nomor pernyataan 4, 9, dan 14 memperoleh nilai sebesar 162 dengan prosentase 93,32 yang berarti bahwa pasien merasa puas. Berdasarkan aspek Jaminan pada nomor pernyataan 5,10 , dan 15 memperoleh nilai sebesar 158 dengan prosentase 91,32 yang berarti bahwa pasien merasa puas.

bahwa setelah dilakukan analisis dengan chisquare didapatkan hasil $p$ value sebesar 0.424 yang berarti bahwa $>0.05$ dapat disimpulkan tidak ada hubungan antara jenis kelamin dengan kepuasan terhadap pelayanan kesehatan di Klinik Pratama Akbid Muhammadiyah Cirebon. 
Tabel 9. Hubungan antara Umur dengan Kepuasan Pasien

\begin{tabular}{cllll}
\hline \multirow{2}{*}{$\begin{array}{c}\text { Umur } \\
\text { (tahun) }\end{array}$} & \multicolumn{4}{c}{ Kepuasan } \\
\cline { 2 - 4 } & $\begin{array}{c}\text { Tidak } \\
\text { Puas }\end{array}$ & Puas & Total & $\begin{array}{c}\boldsymbol{P} \\
\text { value }\end{array}$ \\
\hline $16-24$ & 1 & 6 & 7 & \\
$25-34$ & 1 & 13 & 14 & \\
$35-49$ & 2 & 11 & 13 & 0.883 \\
$50-64$ & 1 & 3 & 4 & \\
$>65$ & 0 & 1 & 1 & \\
\cline { 1 - 3 } Total & $\mathbf{5}$ & $\mathbf{3 4}$ & $\mathbf{3 9}$ & \\
\hline
\end{tabular}

Berdasarkan tabel 9 di atas dapat diketahui bahwa setelah dilakukan analisis dengan chisquare didapatkan hasil $p$ value sebesar 0.883 yang berarti bahwa $>0.05$ dapat disimpulkan tidak ada hubungan antara umur dengan kepuasan terhadap pelayanan kesehatan di Klinik Pratama Akbid Muhammadiyah Cirebon.

Tabel 10. Hubungan antara Pendidikan dengan Kepuasan Pasien

\begin{tabular}{cllll}
\hline \multirow{2}{*}{ Pendidikan } & \multicolumn{4}{c}{ Kepuasan } \\
\cline { 2 - 4 } & $\begin{array}{c}\text { Tidak } \\
\text { Puas }\end{array}$ & Puas & Total & $\begin{array}{c}\boldsymbol{P} \\
\text { value }\end{array}$ \\
\hline SD & 0 & 2 & 2 & \\
SMP & 2 & 5 & 7 & \\
SMA & 1 & 18 & 19 & \\
Diploma & 1 & 4 & 5 & 0.537 \\
Sarjanal & 1 & 5 & 6 & \\
Magister & & & & \\
\hline Total & $\mathbf{5}$ & 34 & 39 & \\
\hline
\end{tabular}

Berdasarkan tabel 10 di atas dapat diketahui bahwa setelah dilakukan analisis dengan chisquare didapatkan hasil $p$ value sebesar 0.537 yang berarti bahwa $>0.05$ dapat disimpulkan tidak ada hubungan antara pendidikan dengan kepuasan terhadap pelayanan kesehatan di Klinik Pratama Akbid Muhammadiyah Cirebon.

Tabel 11. Hubungan antara Pekerjaan dengan Kepuasan Pasien

\begin{tabular}{cllll}
\hline \multirow{2}{*}{ Pekerjaan } & \multicolumn{4}{c}{ Kepuasan } \\
\cline { 2 - 4 } & $\begin{array}{c}\text { Tidak } \\
\text { Puas }\end{array}$ & Puas & Total & $\begin{array}{c}\boldsymbol{P} \\
\text { value }\end{array}$ \\
\hline PNS & 1 & 0 & 1 & \\
$\begin{array}{c}\text { Pegawai } \\
\text { Swasa }\end{array}$ & 1 & 13 & 14 & \\
$\begin{array}{c}\text { Pedagang } \\
\text { Tidak }\end{array}$ & 0 & 3 & 3 & 0.053 \\
$\begin{array}{c}\text { Bekerja } \\
\text { Total }\end{array}$ & $\mathbf{5}$ & 18 & 21 & \\
\hline
\end{tabular}

Berdasarkan tabel 11 di atas dapat diketahui bahwa setelah dilakukan analisis dengan chisquare didapatkan hasil $p$ value sebesar 0.053 yang berarti bahwa $>0.05$ dapat disimpulkan tidak ada hubungan antara pekerjaan dengan kepuasan terhadap pelayanan kesehatan di Klinik Pratama Akbid Muhammadiyah Cirebon.

Tabel 12. Hubungan antara Kepesertaan BPJS dengan Kepuasan Pasien

\begin{tabular}{cllll}
\hline \multirow{2}{*}{$\begin{array}{c}\text { Kepesertaan } \\
\text { BPJS }\end{array}$} & \multicolumn{4}{c}{ Kepuasan } \\
\cline { 2 - 4 } & $\begin{array}{c}\text { Tidak } \\
\text { Puas }\end{array}$ & Puas & Total & $\begin{array}{c}\boldsymbol{P} \\
\text { value }\end{array}$ \\
\hline Umum & 1 & 13 & 14 & \\
BPJS & 4 & 21 & 25 & 0.427 \\
\hline Total & $\mathbf{5}$ & $\mathbf{3 4}$ & $\mathbf{3 9}$ & \\
\hline
\end{tabular}

Berdasarkan tabel 13 di atas dapat diketahui bahwa setelah dilakukan analisis dengan chisquare didapatkan hasil $p$ value sebesar 0.427 yang berarti bahwa $>0.05$ dapat disimpulkan tidak ada hubungan antara kepesertaan BPJS dengan kepuasan terhadap pelayanan kesehatan di Klinik Pratama Akbid Muhammadiyah Cirebon.

\section{PEMBAHASAN}

\section{Gambaran Karakteristik Responden}

Berdasarkan hasil penelitian tentang karakteristik responden didapatkan bahwa karakteristik responden penelitian menunjukkan bahwa sebagian besar responden berjenis kelamin perempuan, berpendidikan SMA, berumur 25 - 34 tahun, tidak bekerja, dan menggunakan BPJS sehingga tingkat harapannya juga cukup tinggi. Dalam penelitian ini tingkat harapan sebagian besar pasien adalah puas.

Hal ini sesuai dengan (Hagus Wiyono, 2016) bahwa kondisi ini disebabkan adanya beberapa hal yang mendorong tingkat harapan yang baik, yaitu antara lain dengan adanya program-program yang dicanangkan oleh pemerintah, misalnya program asuransi dan sebagainya. Program asuransi yang dicanangkan oleh pemerintah misalnya BPJS menyebabkan orang-orang dari kalangan pendidikan rendah dan ekonomi rendah juga memiliki kesempatan yang sama dalam memperoleh pelayanan kesehatan. Ketika 
mereka merasa memiliki kemampuan untuk memperoleh pelayanan kesehatan dengan asuransi kesehatan, maka harapan mereka terhadap pelayanan kesehatan juga meningkat.

\section{Gambaran Kepuasan Responden}

Berdasarkan hasil survei yang telah dilakukan tentang kepuasan pasien terhadap pelayanan kesehatan di Klinik Pratama Akbid Muhammadiyah Cirebon didapatkan bahwa tingkat kepuasan yang paling tinggi yaitu pada aspek empati yaitu prosedur pendaftaran mudah dan tidak berbelit - belit, dokter memeriksa dengan ramah dan sopan, dan perawat melayani saya dengan tulus dan penuh kasih sayang dengan bobot 160 (94.15\%).

Pengukuran tingkat kepuasan pelanggan sangat penting, menurut Kotler (2000) dalam Umniyati (2019) pada dasarnya kepuasan dan ketidakpuasan pelanggan atas produk akan berpengaruh pada pola perilaku selanjutnya, hal ini ditunjukkan pelanggan setelah terjadi proses pembelian. Apabila pelanggan merasa puas, maka dia akan menunjukkan besarnya kemungkinan untuk kembali membeli produk yang sama. Pelanggan yang puas juga cenderung akan memberikan referensi yang baik terhadap produk kepada orang lain (Helwiyah Umniyati, 2010)

Menurut Pohan dalam Nurpratama (2019) bahwa para dokter mempunyai kemampuan sehingga mereka dapat sangat mengurangi tekanan psikologi pasien, hanya dengan beberapa kata penenang dan penghibur dengan menunjukkan perhatian dan keterlibatan dalam kesulitan pasien. Menurut Tjiptono dalam Nurpratama bahwa kepuasan pasien didapatkan salah satunya melalui kecepatan yaitu pelayanan perawat melalui pemberian penanganan pasien yang cepat. Hasil penelitian Wiyono dan Wahyuddin (2006) dalam (Linda, 2018) menyatakan bahwa kualitas pelayanan paramedis memiliki pengaruh terbesar terhadap mutu dan kenyamanan pada tempat pelayanan kesehatan.

Kepuasan pelanggan merupakan strategi jangka panjang yang membutuhkan komitmen yang kuat baik menyangkut dana maupun sumber daya manusia (Tjiptono, 2005), sebab kepuasan pelanggan dapat menjadi sarana untuk membangun hubungan yang harmonis antara organisasi dengan pelanggannya, di mana pelanggan yang puas akan kembali memanfaatkan jasa pelayanan dan merupakan langkah awal yang baik sehingga terciptanya loyalitas pelanggan yang dapat dijadikan suatu promosi yang membentuk rekomendasi dari mulut ke mulut, reputasi baik di mata pelanggan, dapat meningkatkan keuntungan bagi organisasi tidak hanya sebatas pada masyarakat yang biasa menggunakan tapi juga masyarakat secara keseluruhan di wilayah kerja Puskesmas. Bila pelanggan tidak puas harus segera dicari penyebabnya dan segera dilakukan koreksi untuk perbaikan pelayanan.

Hal ini sejalan juga dengan Jacobalis (1989) yang menyatakan bahwa tidak mudah untuk memenuhi kepuasan semua pelanggan, lebih-lebih terhadap jasa pelayanan, banyak variabel non medik yang ikut menentukan kepuasan dan ketidakpuasan klien, diantaranya: tingkat pendidikan, latar belakang, sosial ekonomi, budaya, lingkungan fisik, pekerjaan, kepribadian, pengalaman hidup klien.

Menurut Tjiptono (2005) dalam (Hagus Wiyono, 2016) menyatakan bahwa perawat berkewajiban memahami kebutuhan dan keinginan pasien sebagai upaya untuk meningkatkan kepuasan pasien. Pasien yang puas merupakan aset yang sangat berharga karena apabila pasien puas mereka akan terus melakukan pemakaian terhadap jasa pilihannya, tetapi jika pasien merasa tidak puas mereka akan memberitahukan dua kali lebih hebat kepada orang lain tentang pengalaman buruknya.

Berdasarkan hasil survei juga ditemukan masih ada ketidakpuasan pasien terhadap pelayanan dokter yang paling banyak yaitu pasien kurang puas dengan pelayanan dokter umum yang tidak selalu jaga di klinik. Menurut persepsi responden, dokter di Klinik Pratama Akbid Muhammadiyah Cirebon tidak tepat waktu dan tidak selalu berada di klinik, hal ini dapat dimengerti dikarenakan dokter umum 
yang jaga di Klinik Pratama Akbid Muhammadiyah Cirebon juga melakukan praktik dokter di tempat lain sehingga dokter harus mengatur jadwal praktiknya dan tidak bisa tetap berada di Klinik Pratama Akbid Muhammadiyah Cirebon.

Hal ini sudah sejalan dengan Permenkes RI 2007 pasal 4 ayat (1) yang menyatakan bahwa Surat ljin Praktik (SIP) dokter atau dokter gigi diberikan paling banyak untuk 3 (tiga) tempat praktik baik pada sarana pelayanan kesehatan milik pemerintah, swasta maupun praktik perorangan.

\section{Hubungan Jenis Kelamin dengan Kepuasan terhadap Pelayanan Kesehatan}

Berdasarkan hasil analisis bivariat, didapatkan hasil bahwa tidak ada hubungan antara jenis kelamin dengan kepuasan. Menurut Dolinsky dalam (Hidayati, Aulia \& Suryawati, Chriswardani \& Sriatmi, 2014) menyatakan bahwa persepsi dan reaksi terhadap gangguan sakit dipengaruhi oleh sex, ras, pendidikan, kelas ekonomi dan latar belakang budaya. Berdasarkan pernyatan tersebut, antara lakilaki dan perempuan akan relatif sama dalam merasakan kepuasan.

\section{Hubungan Umur dengan Kepuasan terhadap Pelayanan Kesehatan}

Berdasarkan hasil analisis bivariat, didapatkan hasil bahwa tidak ada hubungan antara umur dengan kepuasan. Hal ini sesuai dengan penelitian yang dilakukan oleh (Anjaryani, 2010) yaitu tidak terdapat hubungan antara umur dengan kepuasan pasien rawat inap terhadap pelayanan perawat di RSUD Tugurejo Semarang. Hasil penelitian (Anjaryani, 2010) menunjukkan bahwa responden dengan kategori umur dewasa mempunyai kepuasan paling tinggi (54.8\%) dibandingkan dengan umur anak-anak dan tua, meskipun pasien rata-rata menyatakan puas dalam menilai pelayanan yang diberikan oleh perawat.

\section{Hubungan Pendidikan dengan Kepuasan terhadap Pelayanan Kesehatan}

Berdasarkan hasil analisis bivariat, didapatkan hasil bahwa tidak ada hubungan antara pendidikan dengan kepuasan. Hal ini tidak sesuai dengan penelitian yang dilakukan oleh (Anjaryani, 2010) yaitu terdapat hubungan antara pendidikan dengan kepuasan pasien rawat inap terhadap pelayanan perawat di RSUD Tugurejo Semarang.

Menurut Mar'at dalam (Hidayati, Aulia \& Suryawati, Chriswardani \& Sriatmi, 2014) menyatakan bahwa perasaan puas pada setiap individu tidaklah sama, akan tetapi ungkapan puas pada sekelompok individu dapat terjadi hampir sama karena adanya pengaruh lingkungan dan masyarakat dengan golongan tertentu. Menurut Jacobalis dalam (Mulyani, 2014) tingkat pendidikan dapat memengaruhi pola pikir rasional dan irasional seseorang mengambil keputusan menggunakan/ memanfaatkan suatu pelayanan kesehatan. Responden yang didominasi latar belakang pendidikan rendah SD/SMP memiliki kecenderungan inkonsistensi persepsi yang tinggi (tidak tetap pendirian) mudah dipengaruhi/ dibandingkan dengan latar belakang pendidikan tinggi.

\section{Hubungan Pekerjaan dengan Kepuasan terhadap Pelayanan Kesehatan}

Berdasarkan hasil analisis bivariat, didapatkan hasil bahwa tidak ada hubungan antara pekerjaan dengan kepuasan. Hal ini sesuai dengan penelitian yang dilakukan oleh (Anjaryani, 2010) yaitu tidak terdapat hubungan antara pekerjaan dengan kepuasan pasien rawat inap terhadap pelayanan perawat di RSUD Tugurejo Semarang.

Menurut Endang Ekowarni dalam (Anjaryani, 2010) menyatakan bahwa jenis pekerjaan dapat memengaruhi kepuasan pasien atas pelayanan yang diselenggarakan oleh Rumah Sakit, contohnya pada pasien yang pekerjaan sehari-harinya sebagai pejabat Pemerintah atau PNS atau aparat militer dengan pangkat tinggi, kadang lupa bahwa dokter dan perawat adalah orang yang membantu untuk mengatasi penyakit yang dideritanya dan mereka lebih banyak menganggap bahwa dokter dan perawat sebagai staf atau bawahan mereka, yang bisa menuruti atau mematuhi perintah mereka setiap dibutuhkan, sehingga mereka cenderung seenaknya terhadap kehadiran dokter dan 
perawat. Sedangkan pasien yang bekerja sebagai buruh cenderung takut untuk bertanya kemajuan pengobatan terhadap penyakit yang dideritanya, sehingga mereka lebih banyak diam dan bersifat pasif, karena status yang mereka miliki atas pekerjaan yang mereka lakukan dianggap "tidak mampu" untuk mempertanyakan kemajuan pengobatan dan pelayanan. Mereka cenderung lebih menerima dengan kondisi pelayanan yang diberikan oleh pemberi pelayanan.

\section{Hubungan Kepesertaan BPJS dengan Kepuasan terhadap Pelayanan Kesehatan}

Berdasarkan hasil analisis bivariat, didapatkan hasil bahwa tidak ada hubungan antara kepesertaan BPJS dengan kepuasan. Hal ini tidak sesuai dengan penelitian yang dilakukan oleh (Endartiwi, Sri S \& Setianingrum, 2018) yaitu terdapat hubungan antara kualitas pelayanan dengan kepuasan peserta JKN di fasilitas kesehatan tingkat pertama provinsi Daerah Istimewa Yogyakarta. Hasil penelitian menunjukkan bahwa fasilitas pelayanan kesehatan pertama yang terdiri dari Puskesmas, Dokter Praktik Swasta, dan Klinik Pratama yang memberikan pelayanan kepada pasien peserta program Jaminan Kesehatan Nasional (JKN) di Provinsi Daerah Istimewa Yogyakarta sudah baik dan pasien merasakan puas dengan pelayanan yang diberikan tersebut.

Menurut Arifin (2013) dalam (Endartiwi, Sri S \& Setianingrum, 2018) menyatakan bahwa bukti langsung pelayanan yang sudah baik adalah kondisi ruang perawatan yang bersih dan didukung tersedianya fasilitas penunjang di ruang perawatan seperti WC, kenyamanan ruang perawatan dan penampilan petugas kesehatan yang rapi dan bersih. Hasil penelitian pasien bahwa bukti langsung pelayanan kesehatan berhubungan dengan kepuasan pasien pengguna ASKES Sosial pada pelayanan rawat inap.

\section{KESIMPULAN DAN SARAN}

Hasil penghitungan tingkat kepuasan pada aspek berwujud, aspek keandalan, aspek empati, ketanggapan dan aspek jaminan dari pelayanan kesehatan yang meliputi loket pendaftaran, pelayanan dokter umum, dan pelayanan perawat menunjukkan bahwa ratarata menunjukkan bahwa responden merasa puas dengan pelayanan kesehatan yang diberikan oleh Klinik Pratama Akbid Muhammadiyah Cirebon.

Berdasarkan kelima aspek yang dinilai untuk mengetahui tingkat kepuasan pasien terhadap pelayanan kesehatan di Klinik Pratama Akbid Muhammadiyah Cirebon menunjukkan bahwa pasien merasa puas dengan bobot rata-rata 158 dan prosentase rata-rata sebesar 92.09. Tidak ada hubungan antara jenis kelamin, umur, pendidikan, pekerjaan, kepesertaan BPJS dengan kepuasan pasien terhadap pelayanan kesehatan di Klinik Pratama Akbid Muhammadiyah Cirebon.

Berdasarkan kesimpulan di atas maka ada beberapa saran antara lain: perlu meningkatkan kembali pelayanan yang diberikan oleh perawat dengan memberi pelatihan tentang komunikasi dan konseling, Waktu pelayanan dokter lebih ditingkatkan kembali dengan datang tepat waktu sehingga pasien tidak terlalu lama menunggu dan lebih cepat mendapat pelayanan pengobatan, perlu melibatkan seluruh komponen yang ada untuk mengoptimalkan pelayanan kesehatan di Klinik Pratama Akbid Muhammadiyah Cirebon agar lebih bermutu.

\section{REFERENSI}

Adliyani, Z. O. N. (2015). Pengaruh Perilaku Individu terhadap Hidup Sehat. Majority, 4, 109-113.

Anjaryani, W. D. (2010). Kepuasan Pasien Rawat Inap terhadap Pelayanan Perawat di RSUD Tugurejo Semarang. In UNDIP Website. Universitas Diponegoro.

Eliana \& Sumiati, S. (2016). RI, Kesehatan Masyarakat. Pusdik SDM Kesehatan Kemenkes.

Endartiwi, Sri S \& Setianingrum, P. D. (2018). Kualitas Pelayanan Berhubungan dengan Kepuasan Peserta JKN di Fasilitas Kesehatan Tingkat Pertama Provinsi Daerah Istimewa Yogyakarta. http://dx.doi.org/10.22435/hsr.v22i3.897

Hagus Wiyono. (2016). Gambaran Tingkat Kepuasan Pasien Tentang Pelayanan di Instalasi Gawat Darurat Rumah Sakit Umum Daerah Sukoharjo. Publikasi IImiah.

Helwiyah Umniyati. (2010). Kepuasan pasien terhadap 
pelayanan tenaga kesehatan di Puskesmas Kecamatan Tanjung Priok Jakarta Utara Tahun 2009. Faculty of Medicine, 1.

Hidayati, Aulia \& Suryawati, Chriswardani \& Sriatmi, A. (2014). Analisis Hubungan Karakteristik Pasien dengan Kepuasan Pelayanan Rawat Jalan Semarang Eye Center (SEC) Rumah Sakit Islam Sultan Agung Semarang. Jurnal Kesehatan Masyarakat (e-Journal), 2.

Linda, W. (2018). No Title. Journal of Health Science and Prevention, 009-020.

Mulyani, R. (2014). Hubungan Karakteristik Pasien dengan Kepuasan Pelayanan Gizi di Ruang Rawat Inap Rumah Sakit. Jurnal Keperawatan, $X$, 231-240.
Nurpratama, M. (2019). Kepuasan Pasien terhadap Pelayanan Kesehatan: Studi Deskriptif pada Klinik Jantung Hasna Medika Indramayu. Jurnal Investasi, 5, 1-12.

Sri Handayani. (2016). Tingkat Kepuasan Pasien terhadap Pelayanan Kesehatan di Puskesmas Baturetno. 14.

Supranto. (2011). Pengukuran Tingkat Kepuasan Pelangan. 